\title{
Anticorpo Monoclonal Contra uma Proteína Macho-Específica de 19 kDa em Espermatozóides Bovinos: uma Metodologia Promissora para Imunosexagem
}

\author{
Clóvis José Pascarelli Souza ${ }^{1,5}$, Marcos Fernandes Resende da Matta ${ }^{1}$, Gilson Mendes \\ Cruz $^{1,4}$, Elias Walter Alves ${ }^{2}$, Milton Massaricho Kanashiro ${ }^{3}$, José Frederico Straggiotti Silva ${ }^{1}$
}

\begin{abstract}
RESUMO - Neste trabalho, foi purificada uma proteína macho específica com peso molecular de 19 Kda, a partir de espermatozóides de bovinos, por intermédio de cromatografia de gel filtração. O anticorpo monoclonal (Mab) desenvolvido (C11F) contra esta proteína discriminou duas populações de espermatozóides, como revelado por imunofluorescência em microscopia e citometria de fluxo. O epitopo reconhecido pelo Mab C11F esteve presente em 49,7\% da população de espermatozóides. Quando adicionado ao sêmen bovino fresco, o Mab C11F reduziu a motilidade e promoveu a aglutinação dos espermatozóides.
\end{abstract}

Palavras-chave: espermatozóides, bovinos, imunosexagem, proteína macho específica, ac. monoclonal

\section{Monoclonal Antibody against Male-Specific Protein of 19 KDa from Bovine Spermatozoa: A Successful Methodology for Imunosexing}

\begin{abstract}
In this work, a 19KDa, male specific protein, from bovine spermatozoa, was purified using gel filtration chromatography. A monoclonal antibody $(\mathrm{Mab})$ developed $(\mathrm{C} 11 \mathrm{~F})$ against this protein discriminated two populations of spermatozoa, as revealed by immunofluorescence in microscopy and flow citometry. The epitope recognized by Mab C11F was present in $49.7 \%$ of spermatozoa population. When added to fresh bovine semen, the Mab $\mathrm{C} 11 \mathrm{~F}$ reduced the motility and promoted agglutination of the spermatozoa.
\end{abstract}

Key Words: spermatozoa, bovines, immunosexing, male specific protein, monoclonal antibody

\section{Introdução}

A sexagem de espermatozóides, associada à inseminação artificial, propiciará a maximização da produtividade nos programas de cruzamento industrial, possibilitando maior proporção de animais do sexo desejado e considerando as diferentes necessidades de bezerros machos ou fêmeas para criadores de gado de leite ou de corte.

Entre os métodos testados de separação de espermatozóides, para determinação do sexo, estão a centrifugação, com base na massa e motilidade (BAHATTACHARYA et al., 1966 e HAM et al., 1993); a galvanização, com base na carga de superfície (HAFS e BOYD, 1971); a citometria de fluxo (JONHNSON, 1991 e 1992); e a sorologia, com base na detecção de antígenos de superfície celular, por meio de anticorpos (GOLDBERG et al., 1971; KOO et al., 1973). A centrifugação e galvanização parecem não resolver o problema de separação dos espermatozóides " $\mathrm{X}$ " e "Y", pois requerem técnicas de difícil realização, além influir na funcionalidade dos espermatozóides (MORUZZI, 1979 e MEISTRICH, 1982). A citometria de fluxo apresenta dois problemas básicos: primeiro, o número de células tratadas por esse processo é pequeno para as necessidades comerciais da inseminação artificial; segundo, todas as células são submetidas à ação de raio lazer, não estando ainda comprovada a inexistência de efeitos negativos deste sobre o genoma.

Os métodos sorológicos que usam anticorpos monoclonais para a detecção do antígeno H-Y mostram-se promissores, pois, em virtude de serem altamente específicos (PETER et al. 1993), podem ser produzidos em larga escala, apresentam baixo custo de produção, repetibilidade garantida, alta confiabilidade e não comprometem o poder fecundante dos espermatozóides. Porém, existem ainda problemas a serem resolvidos nesta metodologia, no sentido de simplificá-la e torná-la exeqüível industrialmente. Os objetivos deste trabalho foram isolar e purificar uma proteína macho específica de 19 Kda

\footnotetext{
${ }^{1}$ LMGA/Universidade Estadual do Norte Fluminense - Campos.

${ }^{2}$ LQFPP e DBM - ICB/Universidade Federal do Rio de Janeiro.

${ }^{3}$ LBR/Universidade Estadual do Norte Fluminense.

${ }^{4}$ IESES/VFac. Veterinária e Zootecnia de Castelo - Castelo/ES.

${ }^{5}$ FIOCRUZ-RJ.
} 
(BRADLEY, 1989), a partir da membrana plasmática de espermatozóides de bovinos, produzir anticorpos monoclonais a partir desta proteína e verificar a eficiência dos anticorpos obtidos sobre o sêmen a fresco de bovinos.

\section{Material e Métodos}

Foi utilizado sêmen de 15 touros em idade reprodutiva e de raça não definida. A obtenção do sêmen ocorreu por eletroejaculação (TORJET 95 A ELETROVET $^{\mathrm{R}}$ ).

O sêmen fresco fora lavado cinco vezes por centrifugação a $900 \times$ g por 10 minutos em tampão salina fosfatada (PBS), com $\mathrm{pH} 7,4$. Ao final da última lavagem, descartou-se o sobrenadante e $2 \mathrm{ml}$ de tampão TRIS HCl 20 mM, NaCl 150 mM pH 7,4 foram acrescidos ao pelete.

O rompimento das membranas citoplasmáticas foi realizado por sonicação em período de 30 segundos de exposição ao ultra-som e 1 minuto de descanso em gelo. Repetiu-se este procedimento por 10 vezes. A seguir, solubilizaram-se as membranas dos espermatozóides, acrescentado $4 \mathrm{ml}$ de tampão TRIS $\mathrm{HCl} 20 \mathrm{mM}, \mathrm{NaCl} 150 \mathrm{mM}, \mathrm{pH} 7,4$ e $0,1 \%$ do detergente NONIDET NP-40 (Sigma) v/v., mantendo-as sob agitação constante à temperatura de $4^{\circ} \mathrm{C}$ durante 1 hora. A suspensão de membranas solubilizadas foi centrifugada a $5000 \mathrm{x}$ g por 30 minutos.

As frações de proteínas de peso molecular de 19 $\mathrm{kDa}$. foram obtidas por exclusão molecular em coluna com dimensões de $1,6 \mathrm{~cm}$ de diâmetro e $130 \mathrm{~cm}$ de altura, preenchida com $120 \mathrm{ml}$ de resina SephacrylHR-S-200 e equilibrada durante toda a noite à temperatura ambiente com tampão Tris $\mathrm{HCl} 20 \mathrm{mM}, \mathrm{NaCl}$ $150 \mathrm{mM} \mathrm{pH} \mathrm{7,4} \mathrm{e} \mathrm{NONIDET} \mathrm{NP-40} \mathrm{0,1 \%} \mathrm{v/v.} \mathrm{O}$ empacotamento da coluna foi realizado para se obter fluxo de 1,0 $\mathrm{ml}$ por minuto. A suspensão de proteínas de membranas foi aplicada na coluna em volume total de 5,0 ml. Consideraram-se os $30 \mathrm{ml}$ iniciais do eluído como o $\mathrm{V}_{0}$ da coluna e, a seguir, foram obtidas 90 frações de 1,0 ml, coletadas em coletor de frações (FRAC-100/200 R - Pharmacia Biotech). Essas frações foram analisadas a $\mathrm{A}_{280} \mathrm{~nm}$ em espectofotômetro (SPEKOL-ZEISS). As frações foram agrupadas em pools de acordo com o gráfico elaborado a partir da leitura do espectofotômetro.

Por meio de eletroforese em gel de poliacrilamida SDS PAGE na concentração de $15 \%$ identificou-se o pool que apresentou proteínas de $19 \mathrm{kDa}$, as quais foram parcialmente liofilizadas, a fim de diminuir o volume a, aproximadamente, $25 \%$ do volume inicial.
A concentração do pool de proteína foi determinada por corrida eletroforética, em gel de poliacrilamida SDS-PAGE a 15\%, comparando-se $20 \mu 1$ deste pool com mesmo volume de soro albumina bovina em diferentes concentrações $(2,5,7,10,15$, 20 e $30 \mathrm{mg} / \mathrm{ml}$ ). Em diferentes poços do gel foram colocados $20 \mu \mathrm{L}$ da suspensão do pool de proteína e $20 \mu 1$ de cada concentração de soro albumina bovina (BSA). A concentração foi analisada por intermédio do programa computacional de densitometria "GELSCAN" (BOZZO e RETAMAL 1991).

Para a obtenção do anticorpo monoclonal, de acordo com COLIGAN et al. (1991), utilizaram-se três camundongos fêmeas da linhagem BALB/c, as quais foram inoculadas no coxim plantar com $50 \mu \mathrm{g} /$ animal/inoculação da proteína extraída dos espermatozóides, utilizando-se esquema de três aplicações por animal. Na primeira aplicação foi utilizado adjuvante completo de FREUND; a segunda e a terceira aplicações foram realizadas, respectivamente, $15 \mathrm{e}$ 23 dias após a primeira inoculação, sem o adjuvante.

No $24^{\circ}$ dia os animais foram sacrificados por deslocamento cervical e os gânglios poplíteos e linfonodos mesentéricos removidos assepticamente. Esses tecidos, após maceração, sofreram lavagem com PBS pH 7,4. As células oriundas dessa maceração foram fusionadas com mielomas da linhagem NSO de camundongos e mantidas inicialmente em meio DMEM F-12, acrescido de meio seletivo HAT (GIBCO), soro fetal bovino $10 \% \mathrm{v} / \mathrm{v}$ (FAZENDA PIG), penicilina/ estreptomicina (SIGMA) $100 \mathrm{mg} / \mathrm{ml}$ de meio e, após 15 dias, foram mantidos permanentemente em meio sem presença de HAT. Ao final de 15 dias, realizouse teste de ELISA para selecionar os clones positivos à proteína de $19 \mathrm{kDa}$.

Os anticorpos produzidos pelos clones selecionados foram testados por imunofluorescência, de acordo com COLIGAN et al. (1991), para verificar quais promoviam a marcação de população de espermatozóides de bovinos. A seguir, efetuou-se leitura em cell sorter (Coulter Elite/ESP).

\section{Resultados e Discussão}

A purificação das proteínas ocorreu por exclusão molecular, em coluna de Sephacril HR S-200, com coletas de 90 frações de $1 \mathrm{ml}$ e analisadas por espectrofotometria a $\mathrm{A}_{280} \mathrm{~nm}$. Por meio de eletroforese em gel de poliacrilamida foram identificadas e selecionadas as frações que possuíam proteínas de $19 \mathrm{kDa}$, colocadas em pool e, a seguir, 


\section{Rev. bras. zootec.}

parcialmente liofilizadas. A concentração do pool da proteína de $19 \mathrm{kDa}$ foi determinada por comparação em corrida eletroforética com quantidade conhecida de soro albumina bovina (Bs $\Delta$ ), utilizando o programa computacional GELSCAN para a determinação da concentração.

Os anticorpos monoclonais, produzidos a partir de proteínas de $19 \mathrm{kDa}$, quando testados por ELISA, apresentaram 21 clones positivos para esta proteína.

Os hibridomas positivos pelo teste de ELISA foram testados por imunofluorescência em espermatozóides de bovinos, apresentando seis clones que respondiam positivamente apenas para percentual dos espermatozóides. Destes hibridomas, selecionou-se o clone $\mathrm{C} 11 \mathrm{~F}$.

$\mathrm{O}$ clone $\mathrm{C} 11 \mathrm{~F}$, quando testado por imunofluorescência e citometria de Fluxo, demonstrou marcação de 48,2\% dos espermatozóides, con- forme Figura 1. Os espermatozóides, quando visualizados em microscopia, apresentaram-se fluorescentes e não-fluorescentes em campo escuro e claro, respectivamente, conforme a Figura 2.

$\mathrm{O}$ anticorpo monoclonal $\mathrm{C} 11 \mathrm{~F}$ testado em amostras de sêmen recém colhido e não lavado de bovinos apresentou os seguintes resultados:

A) O sêmen em contato com o sobrenadante de cultura de hibridomas, originário do clone $\mathrm{C} 11 \mathrm{~F}$, após 5 minutos, apresentou baixíssima motilidade e formação de grumos de espermatozóides.

B) O sêmen em contato com o sobrenadante de cultura de hibridomas originário do clone $\mathrm{C} 11 \mathrm{~F}$, mais anticorpo contra anticorpo de camundongo, após 5 minutos, apresentou formação de grumos, com baixíssima motilidade.

C) O sêmen em contato com o sobrenadante de

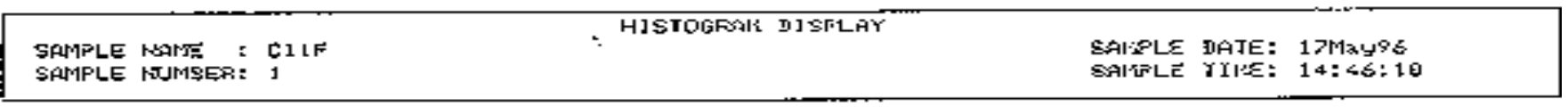

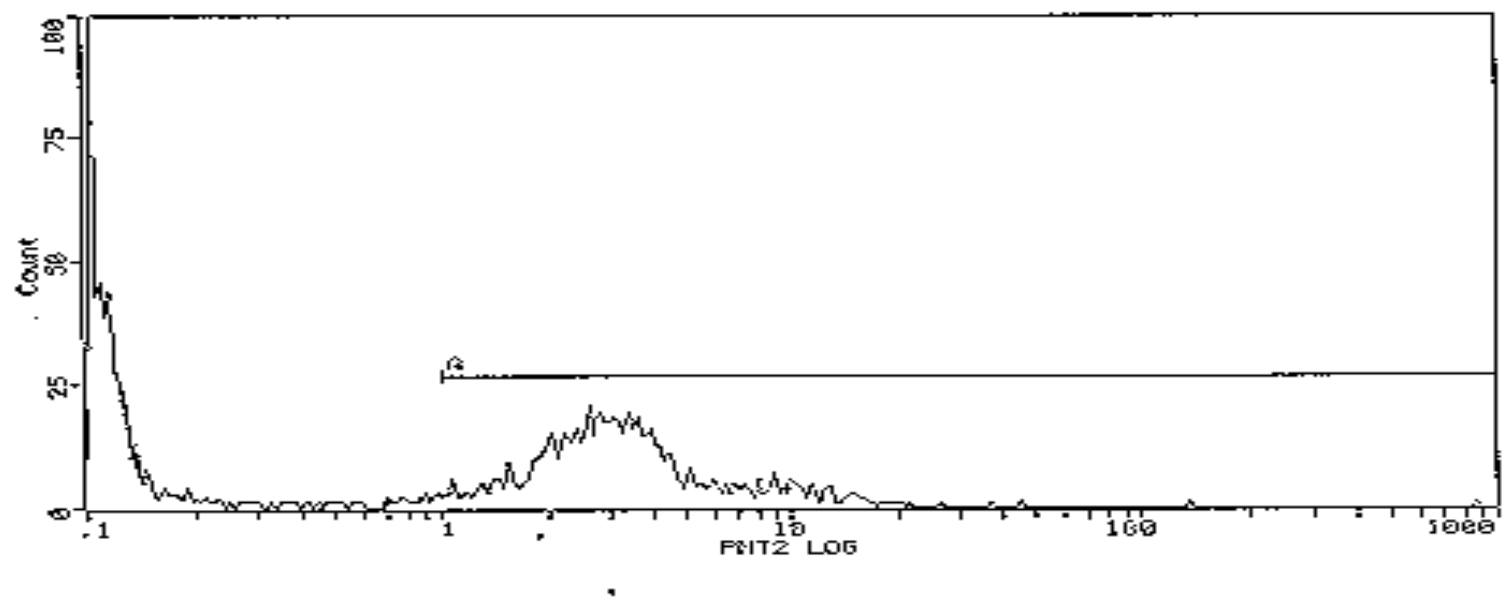

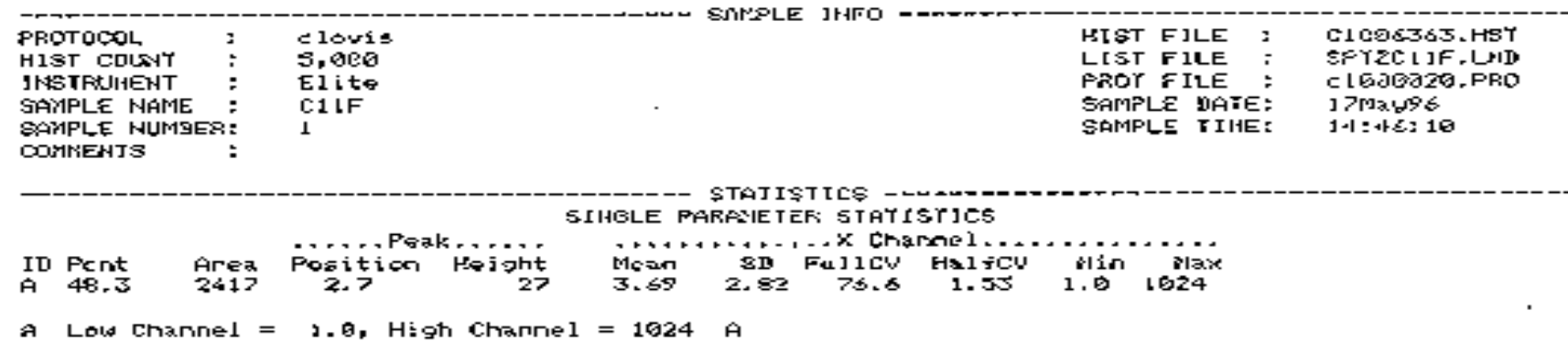

Leitura realizada pela Dra. Andréa Arnhold

Figura 1 - Análise por citometria de fluxo da ação do anticorpo monoclonal C11F, em espermatozóides de bovinos.

Figure 1 - Flow citometric analysis of C11F monoclonal antibody action, in bovine spermatozoa. 
cultura de hibridomas originário do clone $\mathrm{C} 11 \mathrm{~F}$, e após 5 minutos acrescido de complemento de cobaia, apresentou motilidade diminuída, sem formação de grumos.

A produção de anticorpos monoclonais contraantígeno macho específico tem sido descrita como um dos métodos que poderão proporcionar sexagem ideal, devido ao fato de não ser invasivo e ter baixo custo. Os anticorpos anti $\mathrm{H}-\mathrm{Y}$ têm sido utilizados na tentativa de imunosexagem de espermatozóides (PETER et al., 1993) e em sexagem de embriões (BONDIOLI, 1992 e UTSUMI et al., 1993. Neste trabalho procurou-se desenvolver tecnologia eficiente de purificação da proteína de $19 \mathrm{kDa}$, macho específica, assim como a produção de anticorpos monoclonais para esta proteína. Com base nas análises microscópicas por fluorescência de várias amostras de sêmen de bovinos tratados com diferentes anticorpos monoclonais, observou-se que o clone C11F apresentou marcação próxima a 50\% da população dos espermatozóides. A intensidade da marcação observada pelos anticorpos oriundos deste clone, além de constante, demonstrou ser bastante intensa, o que pode pressupor grande avidez e especificidade.

A eficiência deste experimento foi verificada por meio da análise em cell sorter, em que se obtiveram 48,2\% dos espermatozóides marcados.

A seleção do sexo por meio da sexagem de espermatozóides propiciará avanço na tecnologia de sêmen e na tecnologia de embriões. Por ser realizada antes da fecundação e por não possuir ação invasiva, esta técnica deverá ser fonte de incremento à inseminação artificial.

UTSUMI et al. (1993), utilizando anticorpo anti $\mathrm{H}-\mathrm{Y}$ em embriões bovinos, verificou o bloqueio do desenvolvimento desses embriões. Cerca de 80-90\% dos embriões bovinos cujo desenvolvimento não foi influenciado pelo cultivo com anticorpos anti H-Y foram "XX" e, aproximadamente, $80 \%$ dos embriões cujo desenvolvimento foi afetado durante o cultivo eram "XY" (UTSUMI et al. 1993). Este método parece ser vantajoso em relação aos outros utilizados na sexagem de embriões, por ser não invasivo, demonstrando que o antígeno $\mathrm{H}-\mathrm{Y}$ é o meio preciso para se obter sexagem ideal.
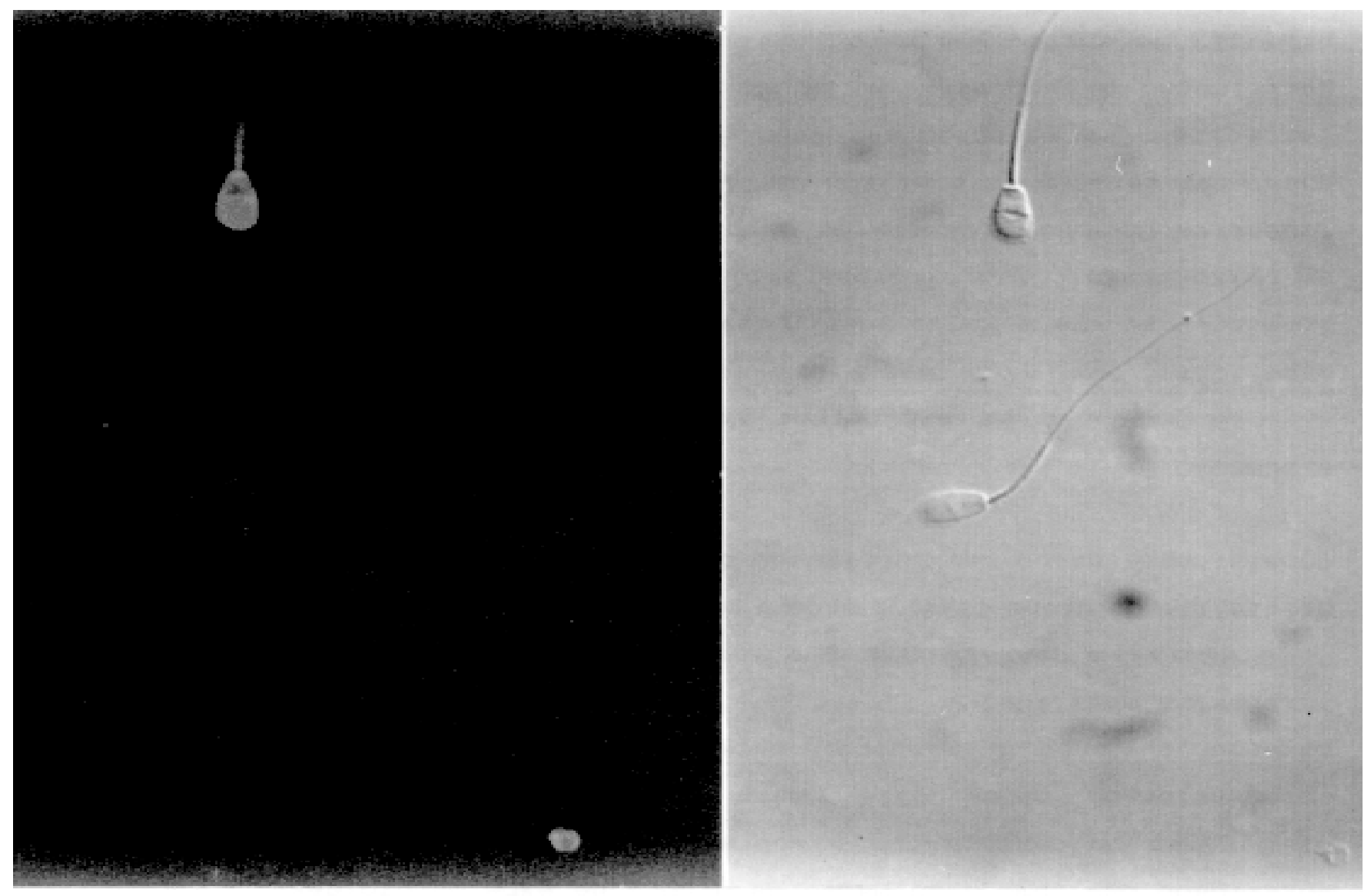

Figura 2 -Imunofluorescência produzida pelo anticorpo monoclonal C11F em espermatozóides bovinos ( campo claro e campo escuro).

Figura 2 - Produced imunofluorescence by C11F monoclonal antibody in bovine spermatozoa (clear field and dark field). 
78 Rev. bras. zootec.

A separação dos espermatozóides portadores do cromossomo " $\mathrm{X}$ " dos portadores do " $Y$ ", por meio de anticorpos monoclonais anti H-Y, fornecerá, sem dúvida, resultados semelhantes aos obtidos por UTSUMI et al.(1993), visto que os resultados parciais obtidos com o clone $\mathrm{C} 11 \mathrm{~F}$, até o presente momento, são muito promissores.

De acordo com MORUZZI (1979), procedimentos envolvendo sedimentação ou centrifugação de espermatozóides que se baseiam na diferença de densidade existente entre os portadores de cromossomo sexuais " $\mathrm{X}$ " ou " $Y$ " requerem técnicas de difícil realização no campo, como a de gradientes de PERCOLL. Além disso, este processo pode influir na funcionalidade dos espermatozóides (MEISTRICH,1982).

\section{Conclusões}

A aplicabilidade comercial da sexagem depende do estabelecimento de metodologia simples que permita: a) processar várias amostras diariamente, a custo baixo (VAN VLECK et al. 1975); b) minimizar a perda de espermatozóides durante o processo; c) maximizar o desvio da proporção do sexo, sem a redução do poder fecundante dos espermatozóides.

A imunosexagem, por ser um método que utiliza anticorpos monoclonais, proporcionará todas as características acima mencionadas. A tecnologia de produção de anticorpos monoclonais propicia a produção em massa de anticorpos altamente específicos, de baixo custo, repetibilidade garantida e alta confiabilidade, sem riscos para o poder fecundante dos espermatozóides.

Para os anticorpos monoclonais desenvolvidos neste trabalho, testes de eficiência do potencial de sexagem estão sendo desenvolvidos, nos quais serão observados as características básicas do sêmen, motilidade, turbilhonamento, concentração, volume e número de células mortas, além do índice de fecundação e percentual de bezerros machos e fêmeas nascidos, dados ainda não analisados.

\section{Referências Bibliográficas}

BAHATTACHARYA, B.C., BANGHAM, A.D., KCRO, R.J. et al. 1966. An attempt to predetermine the sex of calves by artificial insemination whith spermatozoa separeted by sedimentation. Nature, 211:863.

BONDIOLI, K.R. 1992. Embryo sexing: a review of current techniques and their potential for commercial application in livestock production. J. Anim. Sci., 70:19-29.
BOZZO, S., RETAMAL, C.A. 1991. Geles unidimensionales Um nuevo método densitométrico para computadores personales. Arch. Biol. Med. Exp., 24:181.

BRADLEY, M.P. 1989. Immunological Sexing of Mammalian Semen: Current Status and Future Options. J. Dairy Sci. 72:3372-3380.

COLIGAN, J.E., KRUISBEEK, A.M., MARGULIES, D.H. et al. 1991. Antibody Detection and Preparation. In: Currents Protocols in ImmunologyI, Jonh Wiley e Sons (editor), New York, V.1 capit. 2 part. 2 pg 2.5.1-2.6.6.

GOLDBERG, H.G., BOYSE, E.A., BENNETT, D. 1971. et al. Serological demonstration of H-Y (male) antigen on mouse sperm. Nature, 232:478-480.

HAFS, H. D., BOYD, L.J. 1971. Galvanic separation of Xand Y-chromosome bearing sperm. In Sex Ratio at birthprospects for control (C. A. Kiddy and H. D. Hafs, eds.). Am. Soc. for Anim. Sci., p.85-97.

HAM, T.L., FLAHERTY, S.P., FORD, J.H. et al. 1993. Detection of X- and Y- bearing human spermatozoa after motile sperm isolation by swim-up. Fertility and Sterility, 60(6):1046-1051.

JOHNSON, L.A. 1991. Sex preselection in swine: altered sex ratios in offspring following surgical insemination of flow sorted Xand Y-bearing sper. Reprod. Dom. Animal, 26:309-314.

JOHNSON, L. A. 1992. Gender preselection in domestic animals using flow cytometrically sorted sperm. J. Anim. Sci., v.70, suppl.2, p. 8-18.

KOO, G.C., STACHPOLE, C.W., BOYSE, E.A. et al. 1973. Topographical location of H-Y antigen on mouse spermatozoa by immunoelectronmicroscopy. Proc. Nat. Acad. Sci., 70:1502-1505.

MEISTRICH, M. L. 1982. Potential and limitation of physical methods for separation of sperm bearing an $\mathrm{X}$ - or $\mathrm{Y}$ chromosome. In: Prospects for sexing mammalian sperm (R.P. Amann and G. E. Seidel eds.), Colorado Associated University Press, Boulder, Colorado, p. 157-168.

MORUZZI, J.F. 1979. Selecting a mammalian species for the separation of X-and Y-chromosome-bearing spermatozoa. J. Reprod. Fertil., 37:319-323.

PETER, A. J., JONES, P.P., ROBINSON, J.P. 1993. Fraction of bovine spermatozoa for sex selection: A rapid immunomagnetic technique to remove spermatozoa that contain the $\mathrm{H}-\mathrm{Y}$ antigen. Theriogenology, 40:1177-1185.

UTSUMI, K., HAYASHI, M., TAKAKURA, R. et al. 1993. Embryo sex selection by a rat male-specific antibody and the cytogenetic and developmental confirmation in cattle embryos. Mol. Reprod. and Devel., 34:25-32.

VAN VLECK, L.D., EVERETT, R. W. 1975. Genetic value of sexed semen to produce dairy heifers. J. Dairy Sci., 59(10):1802-1808.
Recebido em: $13 / 06 / 97$ Aceito em: 28/08/98 